\title{
Paweł Mecner (2020): Układ scalony. Gramatyka faz i etykiet, Kraków: Universitas, 148 s., ISBN 978-83-242-3576-6.
}

DOI: https://doi.org/10.19195/0137-1169.40.11

„Układ scalony. Gramatyka faz i etykiet” Pawła Mecnera jest próbą przedstawienia polskiemu czytelnikowi szerokiej agendy badawczej biolingwistyki - interdyscyplinarnej dziedziny naukowej badającej język z perspektywy matematyczno-przyrodniczej. Biolingwistyka obejmuje niezwykle rozbudowany zakres badań: począwszy od zachowań komunikacyjnych w świecie biologicznym, przez ewolucje języka naturalnego, aż po procesy umysłowe związane z produkcją i percepcją mowy (Nowakowski 2006:144). Takie spojrzenie na język naturalny jest bliższe naukom ścisłym i przyrodniczym niż naukom humanistycznym, w obrębie których - przynajmniej w Polsce - językoznawstwo lokuje się ze względu nie tylko na zakres badań, lecz także na metody badawcze, to jest użycie procedur nauk przyrodniczych, umożliwiających falsyfikację, oraz wykorzystanie modelowania i dedukcji. Rozwój biolingwistyki związany jest z mentalistycznym spojrzeniem na język naturalny wyrażonym w nowszych pracach Noama Chomskiego $(2000,2007)$, w których poświęca on uwagę „stanom językowym umysłu” i ich biologicznym uwarunkowaniom (Stalmaszczyk 2018:53). W ujęciu biolingwistycznym język rozumiany jest jako zdolność umysłowa, charakterystyczna dla gatunku ludzkiego, umożliwiająca tworzenie struktur hierarchicznych teoretycznie nieskończenie rozbudowanych. Zdolność językowa współpracuje z innymi modułami umysłu, takimi jak: system myślowy, system sensoryczno-motoryczny oraz pamięć, tworząc tytułowy „układ scalony”, umożliwiający człowiekowi komunikację za pomocą języka naturalnego.

Praca Mecnera ma układ modułowy i składa się z trzech części, które - zgodnie z intencją autora - mogą być czytane niezależnie od siebie. Pierwsza część jest wprowadzeniem do biolingwistyki, w którym autor skupia się na wrodzonej zdolności człowieka do tworzenia struktur hierarchicznych o dyskretnej nieskończoności. Tak pojmowany język jest bytem mentalnym (tak zwany I-language / internal language, czyli język wewnętrzny) właściwym gatunkowi ludzkiemu. To właśnie perspektywa języka wewnętrznego wyznacza główne kierunki badań biolingwistycznych, takie jak: wykształcenie zdolności językowej człowieka w procesie ewolucji, różnice pomiędzy językiem człowieka a komunikacją w świecie zwierząt, uwarunkowania genetyczne i neurofizjologiczne pozwalające na produkcję i recepcję mowy oraz współdziałanie języka wewnętrznego z innymi modułami ludzkiego umysłu. W części drugiej autor prezentuje podstawy składni kartograficznej ze szczególnym uwzględnieniem rozbudowania opisu tak zwanej lewej peryferii zdania poprzez rozbicie projekcji CP na pomniejsze projekcje funkcjonalne przedstawiające strukturę tematyczno-rematyczną zdania (zob. Rizzi 1997). Rozważania o projekcjach funkcjonalnych stanowią punkt wyjścia do wprowadzenia najnowszego modelu składni generatywnej, czyli modelu fazowego. Paweł Mecner szczegółowo przedstawia najnowszy w nurcie generatywnym model składniowy, skupiając się na najważniejszych jego elementach: definicji i roli faz w procesie derywacji oraz podstawowych operacjach składniowych, to jest scalaniu Merge i systemie zgody Agree. Opis składni fazowej ma formę chronologicznego przeglądu najnowszych prac Noama Chomskiego, w których ten model został zaproponowany, a następnie w pełni rozwinięty. Ostatnia część książki poświęcona jest analizie struktur składniowych w językach polskim, niemieckim i jidysz, 
w której autor pokazuje różnice między realizacjami podmiotu i dopełnienia w porównywanych językach.

Zaletą książki jest niewątpliwie umożliwienie polskiemu czytelnikowi zapoznanie się z najnowszymi badaniami w obrębie składni generatywnej, które do tej pory dostępne były jedynie w języku angielskim. Autor podjął się trudnego zadania, gdyż oryginalne opisy modelu fazowego zawarte w pracach Chomskiego charakteryzują niezwykle hermetyczny język i terminologia, którą trudno odnieść do terminologii tradycyjnych gramatyk opisowych. Paweł Mecner wykonał ogromną i pionierską pracę zaproponowania nowych polskich terminów, które w jego pracy tworzą spójny obraz modelu fazowego. Zachowują one techniczną naturę oryginałów - mamy zatem podzieloną na fazy derywację, w której podstawowe procesy scalania i zgody operują na elementach leksykalnych (pierwiastkach) i cyklicznie transferują poszczególne części zdania do łączników, czyli modułu semantycznego i fonologicznego. Wszystkie te terminy są nowością w polskim językoznawstwie, chociaż trzeba wspomnieć, że wielu językoznawców w naszym kraju pracuje w nurcie generatywnym, badając język polski, ale publikują oni głównie w języku angielskim. Dopełnieniem polskiej terminologii w omawianej pracy są przykłady z języka polskiego ilustrujące poszczególne elementy modelu. Jednak nasuwa się pytanie, czy we wszystkich przypadkach autor powinien proponować zupełnie nowy termin. Mam tu szczególnie na myśli część książki poświęconą składni kartograficznej, gdzie autor posługuje się terminami „topik” $i$,fokus” w odniesieniu odpowiednio do informacji znanej i nowej. Zamiast zaproponowanych przez autora nowych terminów można wykorzystać już ugruntowany podział na „temat” i „remat” lub też posługiwać się terminami „frazy rematycznej” i „frazy tematycznej” (zob. Grochowski 1986). Podobnie w przypadku tłumaczenia terminu „force” zamiast proponowanej przez autora „mocy zdania” można się posłużyć się już funkcjonującym terminem „siły illokucyjnej” (zob. Austin 1962), który określa, czy dana propozycja jest stwierdzeniem, wykrzyknieniem, czy pytaniem.

Niezaprzeczalną wartością pracy jest zastosowanie omawianych narzędzi teoretycznych w praktyce w ostatniej części książki, w której autor wykorzystuje model fazowy do porównania wybranych struktur składniowych w językach polskim, niemieckim i jidysz. Autor wprowadza rozróżnienie typologiczne na systemy językowe o „silnym T” i „słabym T”, gdzie T odnosi się do projekcji funkcjonalnej obejmującej czas oraz cechy związku zgody (tak zwane „phi features”, czyli osoba, liczba i rodzaj). Języki o silnym T są bogatsze fleksyjnie i pozwalają na opuszczenie podmiotu (na przykład język polski), natomiast języki o słabym $T$ charakteryzują uboższa fleksja i konieczność realizacji fonetycznej podmiotu, chociażby w formie podmiotów ekspletywnych (na przykład języki niemiecki $\mathrm{i}$ angielski). Interesująca $\mathrm{z}$ tego punktu widzenia jest zaprezentowana analiza konstrukcji abiernikowych w jidysz, który łączy w sobie cechy składniowe języków germańskich i słowiańskich. Analiza ta nie tylko wprowadza badanie składni jidysz w nurcie generatywnym na grunt językoznawstwa polskojęzycznego, lecz także pokazuje, jak uniwersalne zasady rządzące składnią języka wewnętrznego mogą tłumaczyć różnice składniowe w poszczególnych gramatykach. Porównanie tych trzech języków pokazuje, że składnia fazowa nie jest jedynie „ćwiczeniem teoretycznym”, ale też praktycznym narzędziem opisu różnic typologicznych.

Wspomniana już modułowa konstrukcja książki pozwala czytelnikowi zgłębić interesujące go zagadnienia bez konieczności czytania całej pracy, jednak przekłada się ona na pewne braki w spójności całego wywodu. Wydaje się, że czytelnik może nie zrozumieć 
związku pomiędzy ujęciem języka jako pewnego obiektu mentalnego a przedstawianymi w pracy abstrakcyjnymi modelami składni. Związek ten powinien zostać bardziej podkreślony na przykład poprzez przedstawienie aspektu psychologicznej realności omawianych modeli składni, a więc pokazanie, że poszczególne jednostki analizy językoznawczej odpowiadają mentalnym procesom tworzenia i rozumienia mowy (Ratner et al. 2005:22). W tym miejscu należy odesłać do badań pokazujących, że mechanizm przetwarzania i rozumienia zdań, czyli „,parser”, kieruje się regułami składni generatywnej. Przykładem może być praca Sadeh-Leicht (2007), który pokazuje, jak tak zwane kryterium tematyczne (Theta Principle) - to jest zasada, że jeden argument czasownika może mieć jedną rolę semantyczną (na przykład agensa), a jedna rola semantyczna może być przypisana jednemu argumentowi (Witkoś 2004:81) - pozwala przewidzieć problemy w przetwarzaniu zdań z wieloznacznością składniową. Innymi słowy, jeśli przetwarzając zdanie, parser nie jest w stanie lokalnie przypisać ról semantycznych argumentom czasownika, to pojawiają się mierzalne trudności w rozumieniu zdania (Sadeh-Leicht 2007:161). Przywołanie podobnych badań psycho- i neurolingwistycznych (zob. Pereplyotchik 2017) w osobnym rozdziale pracy pozwoliłoby czytelnikowi lepiej zrozumieć związki między działaniem ludzkiego umysłu a proponowaną w nurcie generatywnym architekturą języka wewnętrznego.

Podsumowując, „Układ scalony. Gramatyka faz i etykiet” jest pouczającym polskojęzycznym wprowadzeniem do biolingwistyki i najnowszego modelu składni generatywnej. Paweł Mecner omawia różnorodne aspekty badań biolingwistycznych, a także przedstawia model składni fazowej oraz jego zastosowanie w językoznawstwie porównawczym. Dzięki bogatej literaturze przywołanej w tekście książka stanowi też dobry przewodnik po anglojęzycznych pracach badających język ludzki z perspektywy mentalistycznej. Recenzowana praca wraz z poprzednią książką tego autora (Mecner 2007) również wyczerpująco pokazują rozwój językoznawstwa generatywnego od lat pięćdziesiątych XX wieku po drugą dekadę XXI wieku.

\section{Bibliografia}

Austin John, 1962, How to Do Things with Words, Oxford.

Chomsky Noam, 2000, New Horizons in the Study of Language and Mind, Cambridge.

Сномкку Noam, 2007, Biolinguistic explorations: design, development, evolution, w: International Journal of Philosophical Studies 15(1), s. 1-21.

Grochowski Maciej, 1986, Polskie partykuły. Składnia, semantyka, leksykografia, Wrocław.

MeCner Paweł, 2007, Elementy gramatyki umysłu, Kraków.

Nowakowski Paweł, 2006, Emocjonalne podłoże wypowiedzi językowych. Zarys problematyki z perspektywy biolingwistyki, w: Język, Komunikacja, Informacja 1, s. 143-155.

Pereplyotchik David, 2017, Psychosyntax. The Nature of Grammar and its Place in the Mind, Cham.

Ratner Nan Bernstein / Gleanson Jean Berko / Narasimhan Bhuvana, 2005, Wprowadzenie do psycholingwistyki - wiedza użytkowników języka, w: Gleason J.B. / Ratner N.B. (red.), Psycholingwistyk, Gdańsk, s. 15-64.

Rizzi Luigi, 1997, The fine structure of the left periphery, w: Haegeman L. (red.), Elements of Grammar, Dordrecht, s. 281-337.

Sadeh-Leicht Oren, 2007, The Psychological Reality of Grammar. The Theta Principle in Parsing Performance, Utrecht. 
Stalmaszczyk Piotr, 2018, O paradygmatach w językoznawstwie (na przykładzie językoznawstwa generatywnego), w: Linguistica Copernicana 15, s. 37-59.

Witkoś Jacek, 2004, Movement Rules. Foundations of GB Syntax of English, Poznań.

Marcin Orszulak

ORCID: 0000-0002-6771-8485

Uniwersytet Wrocławski, Polska

Studia Linguistica 40, 2021

(C) for this edition by CNS 